\title{
Ptomaphagus thebeatles n. sp., a previously unrecognized beetle from Europe, with remarks on urban taxonomy and recent range expansion (Coleoptera: Leiodidae)
}

\author{
Menno Schilthuizen \\ Naturalis Biodiversity Center, Darwinweg 2, 2333 CR Leiden, The Netherlands \\ Taxon Expeditions, Rembrandtstraat 20, 2311 VW Leiden, The Netherlands \\ Institute of Biology Leiden, Leiden University, Sylviusweg 72, 2333 BE Leiden, The Netherlands \\ menno.schilthuizen@naturalis.nl \\ Wesley van Oostenbrugge \\ Naturalis Biodiversity Center, Darwinweg 2, 2333 CR Leiden, The Netherlands \\ Department of Forensic Research, Hogeschool van Amsterdam, Weesperzijde 19o, 1097 DZ \\ Amsterdam, The Netherlands
}

\section{Stefan Visser}

Naturalis Biodiversity Center, Darwinweg 2, 2333 CR Leiden, The Netherlands Department of Forensic Research, Hogeschool van Amsterdam, Weesperzijde 19o, 1097 DZ Amsterdam, The Netherlands

Marrit van der Meer

Taxon Expeditions, Rembrandtstraat 20, 2311 VW Leiden, The Netherlands Richard Delval

Taxon Expeditions, Rembrandtstraat 20, 2311 VW Leiden, The Netherlands

\section{Claudia Dias}

Taxon Expeditions, Rembrandtstraat 20, 2311 VW Leiden, The Netherlands

\section{Heko Köster}

Taxon Expeditions, Rembrandtstraat 20, 2311 VW Leiden, The Netherlands

\section{Rudie Maarschall}

Taxon Expeditions, Rembrandtstraat 20, 2311 VW Leiden, The Netherlands 


\title{
Norbert Peeters
}

Taxon Expeditions, Rembrandtstraat 20, 2311 VW Leiden, The Netherlands

\section{Peter Venema}

Taxon Expeditions, Rembrandtstraat 20, 2311 VW Leiden, The Netherlands

\section{Ryan Zaremba}

Taxon Expeditions, Rembrandtstraat 20, 2311 VW Leiden, The Netherlands

Francis W. Parker School, 33 o West Webster Avenue, Chicago, Illinois 6o614, USA

\section{Cristina Beltrami}

Taxon Expeditions, Rembrandtstraat 20, 2311 VW Leiden, The Netherlands

Department of Biotechnology, University of Verona,Strada Le Grazie 15, 37134 Verona, Italy

\section{Marzia Rossato}

Department of Biotechnology, University of Verona, Strada Le Grazie 15, 37134 Verona, Italy

\section{Leonardo Latella}

Museo Civico di Storia Naturale of Verona, Lungadige Porta Vittoria 9, I-37129 Verona, Italy

\section{Florinda Nieuwenhuis}

Gemeente Amsterdam, Ruimte en Duurzaamheid, Weesperplein 8, 1018 XA Amsterdam, The Netherlands

\section{Nicole de Rop}

Gemeente Amsterdam, Ruimte en Duurzaamheid, Weesperplein 8, 1018 XA Amsterdam, The Netherlands

\section{Iva Njunjić}

Taxon Expeditions, Rembrandtstraat 20, 2311 VW Leiden, The Netherlands

Naturalis Biodiversity Center, Darwinweg 2, 2333 CR Leiden, The Netherlands

\section{Michel Perreau}

UT Paris Diderot, Université de Paris, 20 quater rue du département, 75018 Paris, France

\section{Joris M. Koene}

Taxon Expeditions, Rembrandtstraat 20, 2311 VW Leiden, The Netherlands

Vrije Universiteit, De Boelelaan 1085, 1081 HV Amsterdam, The Netherlands

\begin{abstract}
Anthropogenic environmental change is leading to changes in distribution for many organisms. While this is frequently discussed for prominent organisms of high conservation value, the same is true for the many cryptic species that rarely figure in debates on the human impact. One such cryptic taxon


is the European Ptomaphagus sericatus (Chaudoir, 1845) and related forms. During a citizen science expedition in the Vondelpark, Amsterdam, the Netherlands, we obtained two forms of this species complex. We placed the examination of these specimens in the context of a re-analysis of the species group, and, using DNA barcoding and genital study on material collected thoughout Europe, found that the $P$. sericatus species complex consists of three distinct, partly sympatric species, one of which was previously undescribed. On the basis of collection data, at least two species, P. medius and P. thebeatles sp. n., show signs of having recently undergone (possibly anthropogenic) range changes, with $P$. medius even reaching North America. We describe P. thebeatles sp. n.; we raise two subspecies, viz. P. sericatus sericatus (Chaudoir, 1854) and P. sericatus medius (Rey, 1889) to the level of species, and designate a neotype for the former; we identify $P$. dacicus Jeannel, 1934 and $P$. pyrenaeus Jeannel, 1934 as junior synonyms of $P$. sericatus, and $P$. compressitarsus (Rey, 1889) as a junior synonym of $P$. subvillosus Goeze, 1777; we identify $P$. septentrionalis Jeannel, 1934 and $P$. miser (Rey, 1889) as junior synonyms of $P$. medius; we designate lectotypes for $P$. medius and $P$. miser.

\section{Keywords}

citizen science - distribution - Europe - identification - Ptomaphagini - taxonomy

\section{Introduction}

Although the coleopteran fauna of western Europe has been studied intensively for over two centuries and, as it has always been a popular group of insects, their species-level taxonomy has been elucidated to a relatively high degree of accuracy, certain taxa remain poorly understood. One such group is the genus Ptomaphagus Hellwig, 1795 (Leiodidae: Cholevinae; Fig. 1), which consists of a large number of species, all belonging to the nominal subgenus, that are externally very similar and even in male and female genitalia display only subtle interspecific differences. For this reason, a revision of the subgenus Ptomaphagus s.str. is currently under way (Schilthuizen et al., unpubl.). One particularly controversial group within the genus is the species complex surrounding $P$. sericatus (Chaudoir, 1845). Multiple intraspecific taxa have been described (Jeannel, 1936), which have variously been interpreted as good species, subspecies, or taxonomically insignificant variations (Sokolowski, 1956; Szymczakowski, 1956, 1971; Zwick, 1983; Schilthuizen, 1989).

In this paper, we present a separate taxonomic treatment of this species complex. The impetus for this paper was a recent 'taxon expedition', a field course / field trip aimed at discovering and describing new species together with citizen scientists (Schilthuizen et al., 2017). Although taxon expeditions are normally held in remote, poorly studied locations, this particular expedition was to the Vondelpark of Amsterdam, and was meant to highlight the fact that even in the heart of the capital of one of the best studied countries in the world, new discoveries can be made. During this expedition, besides undescribed parasitic Hymenoptera (Van Achterberg et al., 202O), an undescribed member of the $P$. sericatus complex was found. This species had already been recognised previously by one of us (M.S.), and this opportunity was taken to work out a revision of the controversial P. sericatus species complex. 


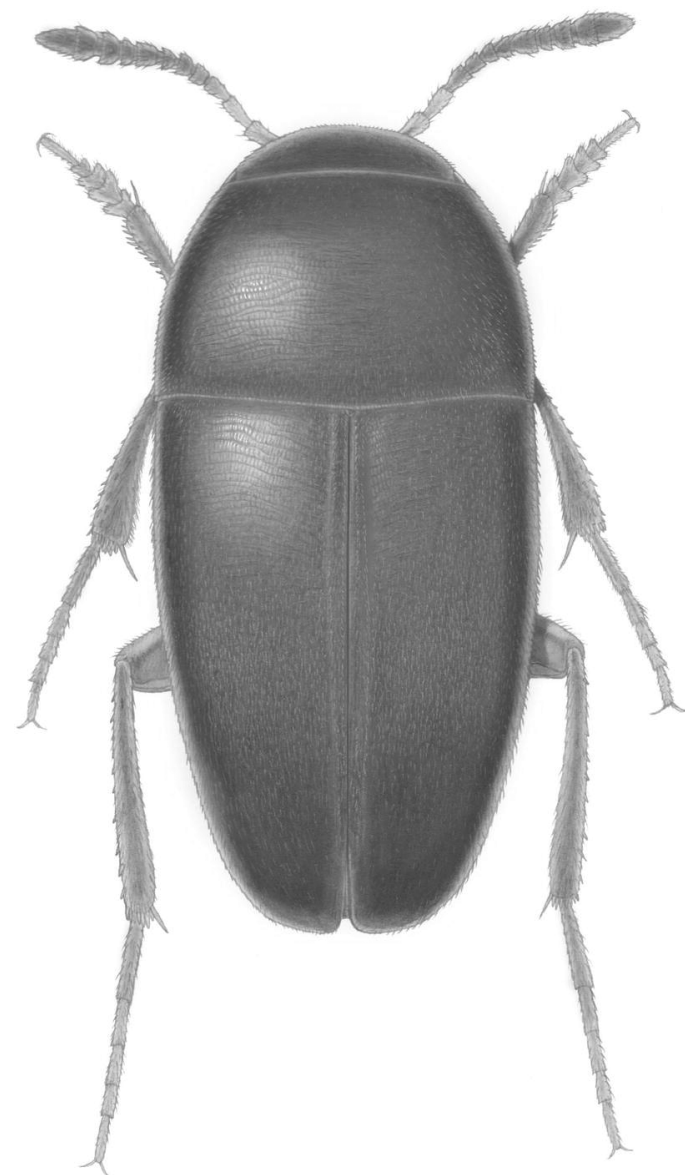

FIgURE 1 Ptomaphagus thebeatles n. sp., habitus. Drawing by Erik-Jan Bosch.

\section{Molecular phylogenetic analysis}

Two individuals of Ptomaphagus thebeatles n. sp., collected during the Vondelpark Taxon Expedition, were treated as follows. Total genomic DNA was isolated from the whole specimen using the DNeasy Blood and Tissue Kit (Qiagen, Hilden, Germany) according to the manufacturer's instructions. Barcoding PCR was conducted by amplifying the mitochondrial gene encoding COI as previously described (Maestri et al., 2019). The following primers, Nancy and Ron (Simon et al., 1994), tailed with adaptors to allow indexing prior to MinION library preparation were used. Nancy:
5'-ACTTGCCTGTCGCTCTATCTTCCCCGGT AAAATTAAAATATAAACTTC-3- and Ron: 5-TTTCTGTTGGTGCTGATATTGCGGAT CACCTGATATAGCATTCCC-3. Each PCR (total volume $25 \mu \mathrm{L}$ ) comprised $2 \mu \mathrm{L}$ of the DNA template, $0.25 \mu \mathrm{M}$ of each primer, $0.25 \mathrm{mM}$ of each dNTP, $1 \times$ Herculase II reaction buffer, and $0.25 \mu \mathrm{L}(20 \mathrm{U} / \mu \mathrm{L})$ of Herculase II fusion DNA polymerase (Agilent Technologies, Santa Clara, CA, USA). The amplification profile consisted of an initial denaturation step (1 min at $94^{\circ} \mathrm{C}$ ) followed by six cycles of $1 \mathrm{~min}$ at $94^{\circ} \mathrm{C}, 90 \mathrm{~s}$ at $45^{\circ} \mathrm{C}$, and $75 \mathrm{~s}$ at $72^{\circ} \mathrm{C}$, then 36 cycles of $1 \mathrm{~min}$ at $94^{\circ} \mathrm{C}, 90 \mathrm{~s}$ at $51^{\circ} \mathrm{C}, 75 \mathrm{~s}$ at $72^{\circ} \mathrm{C}$, and a final extension for $5 \mathrm{~min}$ at 72 ${ }^{\circ} \mathrm{C}$. PCR products were verified by electrophoretic analysis (MiniOne Electrophoresis System, MiniOne Systems) for the presence of unique bands at the expected size ( $500 \mathrm{bp})$ and quantified using a Qubit 2.0 fluorimeter with the Qubit dsDNA BR assay kit (Thermo Fisher Scientific).

To incorporate index sequences and allow the sequencing of multiple samples in each MinION flow cell, a second round of PCR was carried out in a $100 \mu \mathrm{L}$ reaction volume using $48 \mu \mathrm{L}$ of the purified COI-PCR amplicons from the first round ( $0.5 \mathrm{nM}), 2 \mu \mathrm{L}$ of indexed primers provided in the EXP-PBCoor kit (ONT), $0.25 \mathrm{mM}$ of each dNTP, $1 \times$ Herculase II reaction buffer, and $1 \mu \mathrm{L}(20 \mathrm{U} / \mu \mathrm{L})$ of Herculase II fusion DNA polymerase. The amplification profile consisted of an initial denaturation step $\left(3 \mathrm{~min}\right.$ at $95^{\circ} \mathrm{C}$ ) followed by 15 cycles of $15 \mathrm{~s}$ at $95^{\circ} \mathrm{C}, 15 \mathrm{~s}$ at $62^{\circ} \mathrm{C}, 30 \mathrm{~s}$ at $72^{\circ} \mathrm{C}$, and a final extension for $3 \mathrm{~min}$ at $72^{\circ} \mathrm{C}$. Indexed PCR products were purified using o.8X $(8 \circ \mu \mathrm{L})$ AMPureXP beads (Beckman Coulter), quantified as described above and pooled in equimolar concentrations.

Then, $1 \mu \mathrm{g}$ of pooled amplicons was used to prepare sequencing libraries with the SQKLSK1og DNA Sequencing kit (ONT) according to the manufacturer's instructions. The library was loaded on a FLO-MIN1o6 flow cell (R9.4.1 
sequencing chemistry). Sequencing was carried out for $2 \mathrm{~h}$ using MinKNOWv1.6.11 (ONT) on a portable laptop. After MinION sequencing, raw fast5 reads were basecalled and demultiplexed using Guppy v3.2.1+334123b (ONT) with 'fast' configuration. MinION reads were further preprocessed as described in Maestri et al. (2019) and consensus sequences were obtained using ONTrack v1.2.3 with default parameters. All scripts were run within an Oracle Virtualbox v5.1.26 virtual machine emulating an Ubuntu v18.04.2 LTS operating system on a Windows laptop without using any internet connection, and are available at https://github.com/MaestSi/ONTrack.git.

All other samples were treated as follows. DNA extractions were performed on individual legs and/or abdomens using the NucleoMag 96 Tissue kit (Macherey-Nagel Gmbh \& Co., Düren, Germany) on the KingFisher Flex magnetic particle processor (Thermo Scientific). The KingFisher Flex protocols were slightly adjusted from the manufacturer's protocol (http://www.thermoscientific.com) to include longer mixing of beads with lysed sample and a drying step before elution. A volume of $150 \mu \mathrm{l}$ was used for elution. PCR reactions contained 18.75 $\mu$ l ultrapure $\mathrm{H}_{2} \mathrm{O}, 2.5 \mu \mathrm{l}$ 10x PCR buffer, 1. $\mathrm{N} \mu \mathrm{l} 10 \mathrm{mM}$ of each primer, $0.5 \mu \mathrm{l} 2.5 \mathrm{mM}$ dNTPs and $0.25 \mu \mathrm{l} 5 \mathrm{U}$ Qiagen Taq. We amplified part of the cytochrome oxidase I gene of mtDNA using the primers 'Ron', 5'-GGATCACCTGATATAGCATTCCC-3', and 'Nancy', 5'-CCCGGTAAAATTAAAATATAAACTTC-3', of Simon et al. (1994). PCRs were performed using an initial denaturation step of $180 \mathrm{~s}$ at $94^{\circ} \mathrm{C}$, followed by 40 cycles of $15 \mathrm{~s}$ at $94^{\circ} \mathrm{C}$, $30 \mathrm{~s}$ at $5 \mathrm{O}^{\circ} \mathrm{C}$ and $40 \mathrm{~s}$ at $72^{\circ} \mathrm{C}$, and ended with a final extension of $300 \mathrm{~s}$ at $72^{\circ} \mathrm{C}$ and pause at $12{ }^{\circ} \mathrm{C}$. Bi-directional Sanger sequencing was performed at either Macrogen (http://www. macrogen.com) or BaseClear (http://www. baseclear.com).

Sequences were edited manually (primers trimmed off and obvious reading errors corrected) using Sequencher 4.10.1 (Gene Codes Corporation).

In addition to the sequences we generated ourselves, we also obtained Ptomaphagus s. str. sequences available in GenBank and BOLD (Barcoding Of Life Database; www. boldsystems.org). An overview of all the specimens (and their details) for which we have DNA sequences is given in supplementary table Si.

Sequences were aligned in Geneious v.11.1.3, using the MUSCLE algorithm and default settings. Since we used a dataset consisting only of partial COI sequences and therefore not suitable for thorough phylogenetic analysis, we subjected this dataset to a relatively simple analysis, intended primarily for separating the species in the $P$. sericatus complex from each other and from the rest of the subgenus. The alignment (consisting of 137 sequences belonging to 12 putative taxa) was subjected to a maximum-likelihood analysis using PhyML as incorporated in Geneious v.11.1.3 (Guindon et al., 2010), with a GTR substitution model, fixed proportion of invariable sites, 4 substitution rate categories, estimated gamma distribution, and 100 bootstrap replicates. Trees were displayed and manipulated in FigTree v.1.4.2, and Ptomaphagus (Adelops) hatchi Jeannel, 1933 was used as outgroup to root the trees.

\section{Systematic part}

The group comprising Ptomaphagus sericatus (Chaudoir, 1845) and related forms is composed of several taxa that are widespread and common throughout Europe. Some of these have variously been overlooked or misinterpreted. A brief overview of their chequered taxonomic history is therefore warranted.

It is probably best to begin with Jeannel's (1934, 1936) revision, in which he distinguished three subspecies within $P$. sericatus:

(i) the central and east-European $P$. sericatus Downloaded from Brill. comø4/26/2023 12:39:52PM 
sericatus (Chaudoir, 1845), (ii) the Swedish P. sericatus septentrionalis Jeannel, 1934, and (iii) the West European P. sericatus medius (Rey, 1889). He also presented one variety, miser (Rey, 1889) of southeastern France. Jeannel (1936), however, did not clearly specify to which subspecies he considered var. miser to belong, writing that "miser of eastern France is a small-sized variety, which is found mixed with medius, but which, curiously, has the characteristics of the typical sericatus" (our translation). Sokolowski $(1949,1956)$ and Szymczakowski (1971) claim that the differences between $P$. s. sericatus and $P$. s. medius are sufficient to raise medius to the status of separate species. For Central Europe, therefore, they distinguish just two species, $P$. sericatus (of the highlands) and P. medius (of the lowlands). Zwick (1983), however, casts serious doubt on the existence of multiple taxa, stating that he cannot recognize consistent differences in the aedeagus and therefore considers all Central European material as $P$. sericatus. Schilthuizen (1989, 2010), by contrast, reports that the two species are easily distinguishable and sympatric in the Netherlands, and that, moreover, $P$. sericatus s.str. is a recent arrival in that country. The current consensus (Perreau, 200o), however, seems to be that $P$. sericatus consists of two subspecies, $P$. sericatus sericatus and $P$. sericatus medius, that $P$. sericatus septentrionalis has been ignored since Jeannel (1936), and that miser is a variety of medius with no taxonomic validity.

As we show below, aided by molecular phylogenetics, the complex forms a monophyletic group of three genetically and morphologically distinct species, which are sympatric in parts of their range, and have recently undergone significant range shifts. The species are dealt with in detail below, but here follows a synopsis:

- P. thebeatles n. sp. occurs across southern Europe, from the Caucasus to the Iberian peninsula. It is sympatric, in part of its range, with $P$. sericatus and $P$. medius. Its arrival in the Netherlands is, based on collection label dates, probably of relatively recent date. This new species has always been overlooked and usually interpreted as P. sericatus.

- P. sericatus (Chaudoir, 1845) is a mainly central and east-European species. In part of its range, it is sympatric with $P$. thebeatles and with $P$. medius. Some records of $P$. sericatus from the literature probably apply to $P$. thebeatles. $P$. pyrenaeus Jeannel, 1934 is here considered a junior synonym of $P$. sericatus.

- P. medius (Rey, 1889) is a good species from western and northern Europe, covering large parts of Scandinavia, the British Isles, France, the Netherlands, Spain, and Germany. In France and the Netherlands, it is sympatric with $P$. thebeatles. It has recently spread into Hungary, where it is sympatric with $P$. sericatus. It has also recently expanded westward into Canada. P. miser (Rey, 1889) and P. sericatus septentrionalis Jeannel, 1934 are junior synonyms of $P$. medius.

Crucial for this resolution was the study of the type series of Claudius Rey in the Musée des Confluences in Lyon. Rey (1889) described three taxa from the $P$. sericatus complex, namely, $P$. medius, $P$. compressitarsis, and $P$. miser, the latter two having been considered junior synonyms of $P$. medius by Jeannel (1934, 1936), and later authors. For clarity, we here provide the results of our study of all the specimens in Rey's type series:

1. Labelled as "C. compressus" ([sic]; probably an earlier, manuscript version of the published name Catops compressitarsus):

- 1 female without any labels (therefore, from "région Lyonnais sensu lato"; Harold Labrique, pers. comm.). Since Jeannel $(1934,1936)$ stated, for P. compressitarsis (sic): "type: Lyon", we consider this single specimen Downloaded from Brill. c8m04/26/2023 12:39:52PM 
the lectotype for $P$. compressitarsus and have labelled it as such. However, the specimen is, in fact, a $P$. subvillosus, which renders $P$. compressitarsus a junior synonym of $P$. subvillosus (syn. n.).

2. Labelled as "C. medius":

- 1 male with a pale blue round label, which, according to Rey's colour scheme, denotes it was collected in the Pyrénées Orientales (Harold Labrique, pers. comm.). Upon dissection, this specimen indeed has an aedeagus that places it within our interpretation of P. medius. Rey (1889) reports four collection localities for his medius, one of which (Collioure) is in the Pyrénées Orientales and probably concerns this specimen. Jeannel $(1934,1936)$ states, however: "type: Lyon". Jeannel did not see Rey's material and we therefore consider Jeannel's statement not as a lectotypification, but only as a restriction of the type locality, which allows us to designate this specimen (the only "true" $P$. medius in the type series -- see below) as lectotype for Catops medius Rey, 1889. We have labelled it as such.

- 1 male without any labels (i.e., from "région Lyonnais sensu lato"; Harold Labrique, pers. comm.). We dissected this specimen and based on its aedeagus it proved to be a $P$. subvillosus.

- 1 female with a black round label (i.e., from Provence: Var, Alp. Maritimes etc.; Harold Labrique, pers. comm.). We identified this specimen as $P$. subvillosus.

- 1 female with a black round label (i.e., from Provence: Var, Alp. Maritimes etc.; Harold Labrique, pers. comm.). This specimen belongs to the sericatus-group. However, as it is a female, it cannot be unambiguously identified to species level.
3. Labelled as "C. miser":

- 2 males without any labels (therefore, probably from "région Lyonnais sensu lato"; Harold Labrique, pers. comm.). We dissected these specimens and by their aedeagi identified them as $P$. medius. We selected one of these as lectotype of Catops miser Rey, 1889 and labelled it as such.

- 2 females without any labels (therefore, probably from "région Lyonnais sensu lato"; Harold Labrique, pers. comm.). These specimens belong to the sericatus-group. However, as they are females, they cannot be unambiguously identified to species level.

- 1 female with the label "Var". This specimen belongs to the sericatus-group. However, as it is a female, it cannot be unambiguously identified to species level.

Given the external similarity of the three species, we first provide a general description for the $P$. sericatus complex as a whole, and then treat each of the three constituent species, giving cross diagnoses only. In the cross diagnoses, only those traits are mentioned for which we could detect interspecific differences, i.e., the aedeagus and the antennae only. We could not find species-specific differentiation in the spiculum gastrale, the spermatheca, or any other characters.

4. General description for the sericatus-group as a whole:

Habitus: small $(2.4-3.2 \mathrm{~mm})$, long-oval to cuneiform, relatively flat; pronotum as wide as or slightly wider than the elytra; elytra in a gentle curve narrowed apically, their greatest width around one-sixth from the basis; the pronotum deep brown, the elytra often slightly brighter reddish brown. Eyes: relatively small, occupying c. 50\% of the distance between the occipital carina and the antennal basis. Pronotum: rounded laterally, greatest width around one-fifth from the basis, Downloaded from Brill. come4/26/2023 12:39:52PM 
ca. 1.6o times as wide as long; basis sinuous, the lateral corners as well as the central area therefore drawn out caudad; transverse striae conspicuous, relatively widely placed, ca. 30 along the midline. Elytra: relatively flat, with regular, coarse transverse striae spaced slightly more widely than on the pronotum, ca. 30-35 per mm; measured from the tip of the scutellum ca. 1.40 times as long as wide. Antenna: slender, longer than the pronotum, last antennomere as dark as the previous ones, antennal club darker brown than the basis; $3^{\text {rd }}$ antennomere shorter and narrower than the $2^{\text {nd. }}$ Protarsus: dilated in the male, the first 4 tarsomeres jointly 2.5 times as long as broad. Metatibia: straight in the male. Spermatheca: shaped like a narrow "J". Aedeagus: slender, apically gradually narrowed into a symmetric, angular, pointed apex; in lateral view either gradually bent ventrad or with a subapical sinuosity. Genital tergite: Spiculum gastrale long, linear, more than ten times as long as in the middle wide. Caudally widened to a rounded hammer-head shape.

While we were able to discern distinct interspecific differences in the shape of the aedeagus, we have failed to detect interspecific differences in the female spermatheca. However, we cannot exclude the possibility that future studies will reveal diagnostic characters in the spermatheca. Despite subtle differences in the antennal segments, it proved impossible to unambiguously recognise females morphologically. This, plus the fact that most sequenced individuals were deliberately chosen to be males, makes that we lack sufficient reliably identified female material to make pronouncements on the presence or absence of spermathecal differentiation.

\section{Materials and methods}

Material from the citizen science expedition From August $4^{\text {th }}$ until August $9^{\text {th }}$ 2019, a 'taxon expedition' (Schilthuizen et al., 2017) was organised in the 'Koeienweide' $\left(5^{2} .355^{\circ} \mathrm{N}\right.$, $\left.4.8585^{\circ} \mathrm{E}\right)$, a restricted, ecologically managed part of the Vondelpark in the centre of Amsterdam. The area is surrounded by water, and the vegetation consists of reedland and grassland, and fringing strips of woodland consisting of willow, poplar, alder, and other characteristic species of Dutch peatbog areas. During this expedition, citizen scientists used a variety of sampling techniques, including placing meat-baited pitfall traps, to sample the invertebrate fauna. Prior to the expedition, from early March until June, 2019, two of us (M.v.d.M and M.S.) maintained four meatbaited pitfall traps on the Koeienweide, the catch of which was used to obtain preliminary data on the fauna of the area.

\section{Other material studied}

We also studied Ptomaphagus specimens in Naturalis Biodiversity Center, Leiden, the Netherlands (consisting of the former RMNH and ZMAN collections), the Natural History Museum, London, UK (NHMUK), the Zoologische Sammlung des Bayerischen Staates, Munich, Germany (ZSMC), the Hungarian National Natural History Museum, Budapest (HNHM), Museo Civico di Storia Naturale of Verona, Italy (MSNV), Muséum National d'Histoire Naturelle, Paris (MNHN), Musée des Confluences, Lyon, France (MC), collection Jan Ružička, Prague, Czech Republic (CJRP), Collection Národní muzeum, Praha, Czech Republic (NMPC), Collection Taxon Expeditions, Leiden, the Netherlands (TXEX), and collection Michel Perreau, Paris, France (CMPP). Where appropriate, we also included notes on material that we studied previously, from the Zoological Museum of Copenhagen (ZMUC), and the private collection of B.J. van Vondel, Hendrik-Ido-Ambacht (BJVV). We only list material for which the identity was confirmed by dissection of the genitalia and/or DNA-sequencing. Distribution maps 


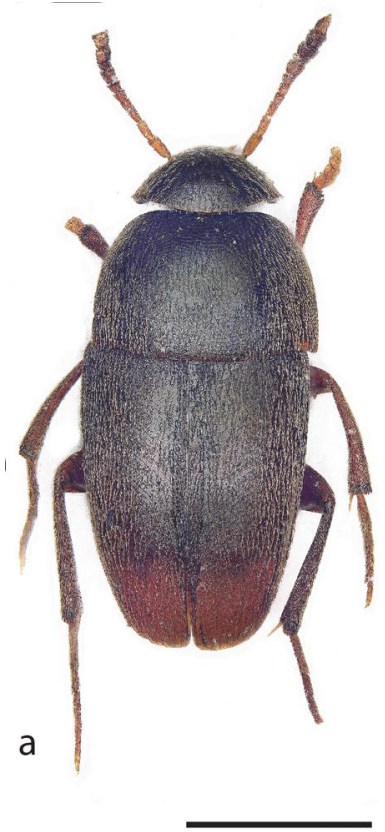

$1 \mathrm{~mm}$

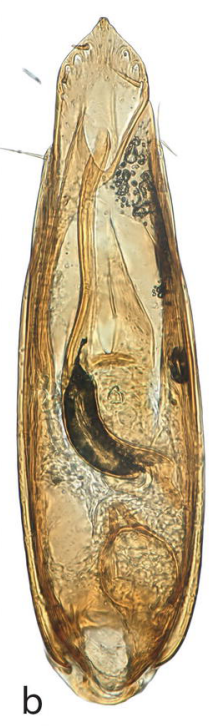

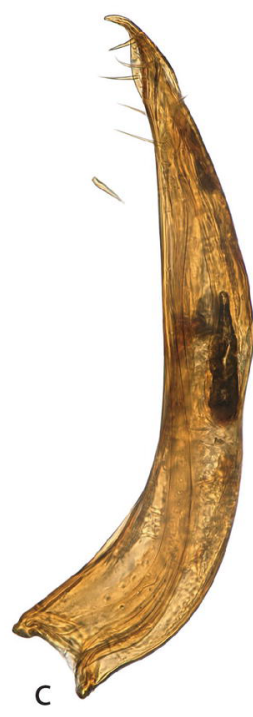

$0.1 \mathrm{~mm}$

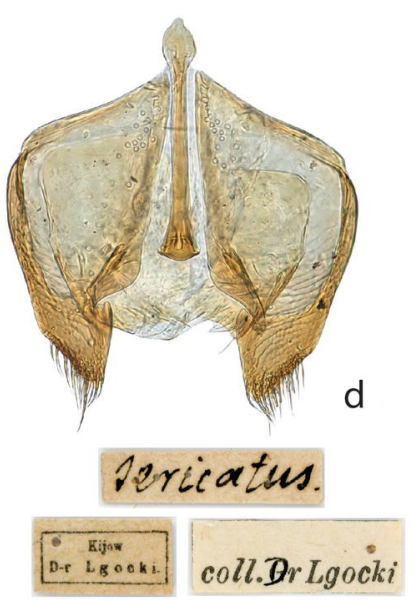

Pf.Senicaths S.Str
det. M. Schilthuizen, 2015

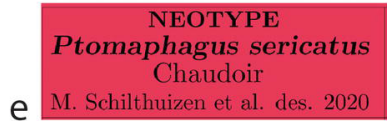

FIGURE 2 Neotype of $P$. sericatus from Kiev, Ukraine: a, habitus; b, aedeagus, dorsal view (angle of view somewhat more rostral than in fig. 4); c, aedeagus, lateral view; d, genital segment; e, labels.

were generated in SimpleMappr (Shorthouse, 2010).

\section{Taxon treatments}

Ptomaphagus (Ptomaphagus) sericatus (Chaudoir, 1845)

\section{Nomenclature}

Catops sericatus Chaudoir, 1845 (Chaudoir, 1845: 199). Holotype (from Kiev) lost. Neotype (here designated) in MNHN. Type locality: Kiev (Fig. 2).

Catops (Ptomaphagus) sericatus Chaudoir, 1845 (Seidlitz, 1887: 93)

Ptomaphagus sericatus (Chaudoir, 1845) (Brancsik, 1907: 6o) (Change of combination) Ptomaphagus subvillosus var. sericatus (Chaudoir, 1845) (Hatch, 1928: 166)

Ptomaphagus (s. str.) sericatus (Chaudoir, 1845) (Jeannel, 1936: 87)

Ptomaphagus (s. str.) dacicus Jeannel, 1934 (Jeannel, 1934: 170). Holotype in MNHN. Type locality: Transylvania: Cluj. syn. n.
Ptomaphagus (s. str.) pyrenaeus Jeannel, 1934 (Jeannel, 1934: 170). Holotype in MNHN. Type locality: France: Basses Pyrénées, grotte de Istaürdy. syn. $\mathbf{n}$.

\section{Examined material}

\section{Type specimens}

Neotype (here designated): "Kijow D-r Lgocki" / "sericatus" [Jeannel's handwriting] / “Coll. Dr Lgocki” / Pt. sericatus s. str. det. M. Schilthuizen 2015" / "NEOTYPE Ptomaphagus sericatus Chaudoir M. Schilthuizen et al. des. 2020" 1 male in MNHN.

The holotype, which should be in Chaudoir's collection in MNHN, has not been found and is presumed lost. We have chosen the specimen above as neotype since it comes fom the type locality as mentioned in the original publication of Chaudoir (Chaudoir, 1845): Kiev in Ukraine. 
Holotype of $P$. dacicus: "Transylvanie Cluj" / "J. Roth 2.viii.25" / "TYPE” [red label] / "MUSÉUM PARIS Coll. R. Jeannel 1931" 1 male in MNHN.

Holotype of $P$. pyrenaeus: "Grotte d'Istaurdie" / "TYPE" [red label] / "MUSÉUM PARIS Coll. R. JEANNEL 1931" 1 male holotype in $\mathrm{MHNH}$.

\section{Other examined specimens}

Austria. Mödling, 1891, leg. Schuster, 1 male in RMNH+ZMAN (ZMA.INS.1141148). Bulgaria. Sliven Kežbonar, 17.vi19o8, leg. Rambousek, 1 male in MNHN. Sofia, viii.19o8, leg. Rambousek, 1 male in MNHN. Croatia. Pakrac, leg. Apfelbeck, 3 males in HNHM. Czechia. Moravia, coll. F. Speiser, 2 males in HNHM. Mähren, Friedland, leg. A. Starhon, 2 males in HNHM. France. Languedoc-Rousillon, Aude, Les Arnoulats, 470 m, 1.ix.2013, leg. W. van Oostenbrugge \& S. Visser, 3 males, 5 females in RMNH+ZMAN (RMNH.INS.63355-63362). Pyrenees, Soula, 42.93573N, 1.6662E, 6oo m, 1.ix.2013; leg. W. v. Oostenbrugge \& S. Visser, 1 male, 2 females in RMNH+ZMAN (RMNH. INS.63369-63371). Grotte d'Istaurdie Bass. Pyr., leg. Jeannel 1931, 1 male in MNHN. Ahusquy B. Pyr., 29.vi.41, 1 male in MSNV. Grotte de Béhérobie, ix.1913, leg. Jeannel, 2 females in MNHN. Entrée grotte d'Istaurdie, ix.1913, leg. Jeannel, 1 male in MNHN. Germany. Halle, Sennewitz SeM, poplar plantation, 22.v.1986, leg. Fritzlar, 1 male in RMNH+ZMAN (RMNH. INS.634235). München, leg. P. Meier, 1 male in RMNH+ZMAN (ZMA.INS.1141331). Hungary. Zala m. Nagyrécse, legelöerdö (déli rész), korhadt fából rostálva, 6.X.2005, leg. O. Merkl \& A. Grabant, 1 male in HNHM. Györ m., Feketeerdö, rostálás, 17.X.1989, leg. O. Merkl, 1 male in HNHM. Pilis-hgys. Lukács-árok, 8.vii.1983, leg. I. Loksa, 1 male in HNHM. Borsod m., Jósvafö, Nagy-oldal, $450 \mathrm{~m}$, korhadt tölgyböl, 21.iv.1992, leg. L. Ádám, 1 male in HNHM. Györ - Sopron m. Feketeerdö,
Felsö-Erdö, talajcsapda 29.viii.1991, leg. L. Ádám, 1 male in HNHM. Györ-M.-S.m., Osli, Tölösi-erdö, 16.iv.1996, leg. A. Podlussány, 1 male in HNHM. Aggleteki National Park, Aggletek, Patkós-oldal, Melittidi-Fagetum, talajcsapda, 2.vi.1987, leg. L. Ádám, 1 male in HNHM. Borsod-A.-Z. m., Miskolc-Pereces, 19.ix.1985, leg. K. Sin, 1 male in HNHM. Békés m., Szarvas, Szarvási Arborétum, romlott húsról, 31.vii.1998, leg. O. Merkl, 1 male in HNHM. Bács-Kiskun m., Karapancsa, keményfaliget, talajcsapda, 14.xi.1991 - 21.iii.1992, leg. I. Loksa, 1 male in HNHM. Aggteleki National Park, Szögliget, Patkós-völgy, MelittidiFagetum, rostálas 25.viii.1987, leg. Ádám \& Szél, 1 male in HNHM. Györ-M.-S. m., Püski, keményfaliget, talajcsapda, 23.vi.-2o.viii.1993, leg. O. Merkl, 1 male in HNHM. Györ-M.-S. m., Dunakiliti, Új-mérés, keményfaliget, rostálás, 14.iii.1994, leg. O. Merkl, 1 male in HNHM. Bükki National Park, Cserépfalu, Hór-vögy, $250 \mathrm{~m}$, farakás alól, rostálás, 12.iv.1984, leg. Merkl \& Korsós, 4 males in HNHM. Fejér m., Martonvásár, Gábori erdö, Sz László, patakpart, talajcsapdából, 19.vi.2O14, leg. M. Molnár, 1 male in HNHM. Balatonkenese, $\mathrm{N} 47^{\circ}$ 2'28,98", E18 $^{\circ} 7^{\prime} 8,6$, 18.v.2O13-2.v.2O14, leg. S. Sághy Szolt, 1 male in HNHM. Kiskunsági National Park, Ócsa, Nagyerdö turjános talajcsapda, 3.viii.-5.ix.1977, leg. Adam \& Hamori, 4 males in HNHM. Budapest, 1903, leg. Diener, 1 male in HNHM. Budapest, Káposztásmegyar, 100 m, nydras, erjedö gyümöks, 9.iv.198o, leg. O. Merkl, 1 male in HNHM. Aggteléki National Park, Szin, Szelcepuszta, Waldsteinio-QuercoCarpinetum, talajcsapda v.1987-v.1988, leg. O. Merkl, 1 male in HNHM. Györ-M.-S. m., Máriakálnok, keményfaliget, rostálás, 9.iv.1994, leg. O. Merkl, 1 male in HNHM. Békés m. Doboz, Kastélypark, 90 m, varjúldagröl, 17.iv.1980, leg. Adám, 1 male in HNHM. Békés m. Gyula, Városerdö, 90 m, rostálás, 29.X.1981, leg. Ádám, 1 male in HNHM. Budapest, coll. Mihók 5.v.1918, 1 male in 
HNHM. Budapest, Füvesz kerz., 8.iv.19o4, leg. Biró, 1 male in HNHM. Pest m. Bag, Zöld-haz, Tuber excavatum, 20.viii.1994, leg. Z. Bratek, 1 male in HNHM. Siófok, leg. Lichteneckert, 1 male in HNHM. Magas-Bakony Kek hegy, talajrostálás, 1.xi.1982, leg. Podlussány \& I. Rozner, 3 males in HNHM. Veszprém m. Bakonynána, 24.iv.1993, leg. O. Merkl, 1 male in HNHM. Pest m., Makád, Duna-ártér, rostálás, 1.v.1991, leg. O. Merkl, 1 male in HNHM. Budapest, Hüvösvölgy, gyermekvasút-állomás, U-vitamin-csapda, 8-17.viii.1992, leg. Z. Bratek, 1 male in HNHM. Budapest, Csücshegy, U-vitamin-csapda, 10-17.viii.1992, leg. Z. Bratek, 1 male in HNHM. Pilis-hgys. Lukácsárok, 8.vii.1983, leg. I. Loksa, 3 males in HNHM. Putnok, coll. E. Frivalszky, 1 male in HNHM. M-Övár, leg. D. Révy, various dates 1941-1945, 3 males in HNHM. Budapest, vicinity of Kamaraerdö, coll. H. Diener, 3 males in HNHM. Budapest, Rákos, v.19o6, coll. H. Diener, 1 male in HNHM. Budapest, Lágymányos, coll. H. Diener, 1 male in HNHM. Budapest, Füveirh, 9.iv.19o4, leg. Biró, 1 male in HNHM. Budapest, Muzeum kerz., 14.xi.1917, leg. Biró, 1 male in HNHM. Csepek, 1 male in HNHM. Zircz, leg. Pavel, 1 male in HNHM. Pécs, 19o9, leg. Kaufmann, 1 male in HNHM. Budapest, leg. Biró, 1 male in HNHM. Italy. Friuli-Venezia Giulia, Noghera, coll. Jeannel, 1 male in MNHN. Poland. Janów ad Olszkyn, 15.iv.1927, 1 male in MHNH. Bouszezów, 17.viii.1938, 1 male in MNHN. Silesia, Blelitz, leg. A. Smolka, 1 male in RMNH+ZMAN (ZMA.INS.1140973). Silesia, Teschen, leg. V. Wanka, 1 male in RMNH+ZMAN (ZMA.INS.1141341). Romania. Bajle Herculane, leg. Machulka, 1 male in MNPC. Herkulesbad, 1895, leg. Ganglbauer, 1 male in MNPC. Gomana Vlaska, leg. A.L. Montandon, 1 male in MNHN. Transylvania, Udvarhely m. Gagy Zálos Tetö, 19.ix.1916, leg. J. Fodor, 1 male in HNHM. Transylvania, Brassó m. Czenk alja, 2.x.1918, leg. J. Fodor, 1 male in HNHM. Transylvania, Szeben m. Nagyszeben,
Burgberg, 20.v.1918, leg. J. Fodor, 1 male in HNHM. Herkulesfürdö, coll. J. Fodor, 1 male in HNHM. Transylvania, Krassó-Szörény m. Mehádja, 17.iv.1915, leg. J. Fodor, 1 male in HNHM. Transylvania, Jud. Cluj. Dej Szölöi erdö, 300 m, Carpinetum, rostálás, 5.viii.1981, leg. Podlussány \& Sacl, 1 male in HNHM. Herkulesfürdö, coll. Mihók, 1 male in HNHM. Krassó-M, 1 male in HNHM. Herkulesfürdó, 1882, leg. Pável, 1 male in HNHM. Krassó-M, 1877, leg. J. Frivalszky \& Pável, 1 male in HNHM. Transsylvania, Hermannstadt (Sibiu), 24.v.1932, coll. Hlisnikowski, 1 male in NMPC. Serbia. Avala near Beograd, 1930, leg. Bischoff, 1 male in MNHN. Slovakia. Pressburger Com., leg. V. Zoufal, 5 males in HNHM. Slovenia. Istria, Mte Tajano, i.viii.1975, leg. Brandmeyr, 1 male in MSNV. Carniolia, coll. Lichtn., 1 male in HNHM. Ukraine. Diwinograd p. Borszizou, 21.vii.1938, 1 male in MNHN. Zezawa o. Zaleszczyki, 6.vii.1935, coll. Tenebaum, 1 male in MNHN. Unknown country. Dormuglet, 1 male in HNHM. Herk., viii.1896, coll. Veth, 1 male in RMNH+ZMAN (RMNH.INS.634084). Karlsburg, leg. Zellich, 1 male in RMNH+ZMAN (ZMA.INS.1141338). Natalia [Natolia?], 5.X.1938, 1 male in MNHN.

\section{Diagnosis}

Antennae (fig. 3a) more robust than in $P$. medius, but more slender than in $P$. thebeatles: $6^{\text {th }}$ antennomere $c .1 .5$ times as wide as long in the male, c. 2 times as wide as long in the female. Aedeagus (fig. 4b) slender and long, tapering gradually towards the apex, and then, near the apical orifice, in a distinct curve; apex in dorsal view triangular, with a $90^{\circ}$ angle, although in more apical view, the very tip is often even sharper; in lateral view not sinuous; apical orifice slightly more basal than the tips of the parameres. 

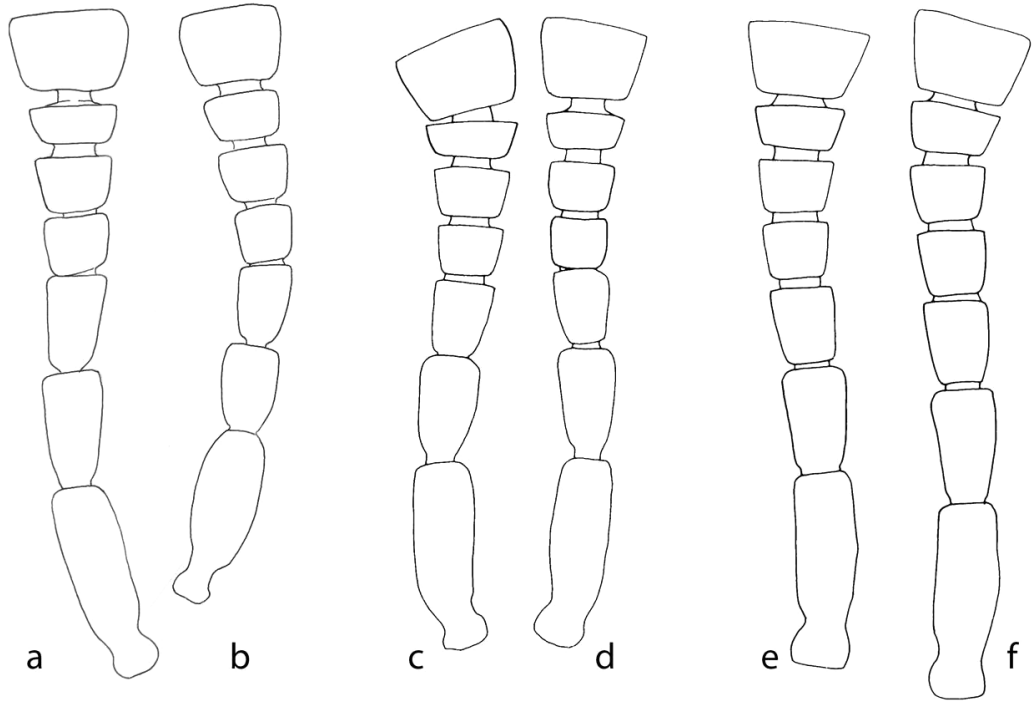

\section{$\widehat{0.05 \mathrm{~mm}}$}

Figure 3 Antennomeres 1-7 for members of the Ptomaphagus sericatus complex. a: P. sericatus, female (a) and male (b) from Les Arnoulats, France. b: P. thebeatles, female (c) from Middelburg, the Netherlands, and male (d) from Schiedam, the Netherlands. After Schilthuizen, 1989. c: P. medius, female (e) from Nieuw \& St. Joostland, the Netherlands, and male (f) from Oostvoorne, the Netherlands. After Schilthuizen, 1989 .

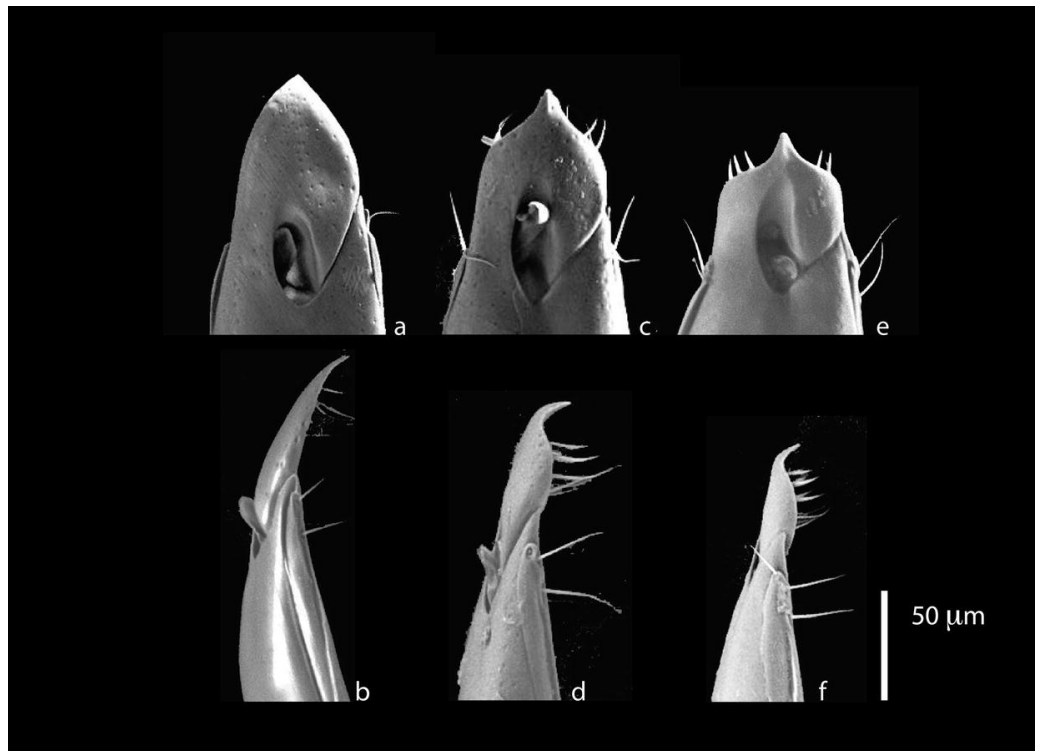

FIGURE 4 Dorsal (perpendicular to the surface of the aedeagus between the orifice and the apex) and lateral views of the apices of the aedeagi of members of the Ptomaphagus sericatus complex. a: P. medius from Oegstgeest, the Netherlands, dorsal (a) and lateral (b) views. b: P. sericatus from Les Arnoulats, France, dorsal (c) and lateral (b) views. c: P. thebeatles from Amsterdam, the Netherlands, dorsal (e) and lateral (f) views. (Images derived from topotypical material, not from the holotype itself.). 


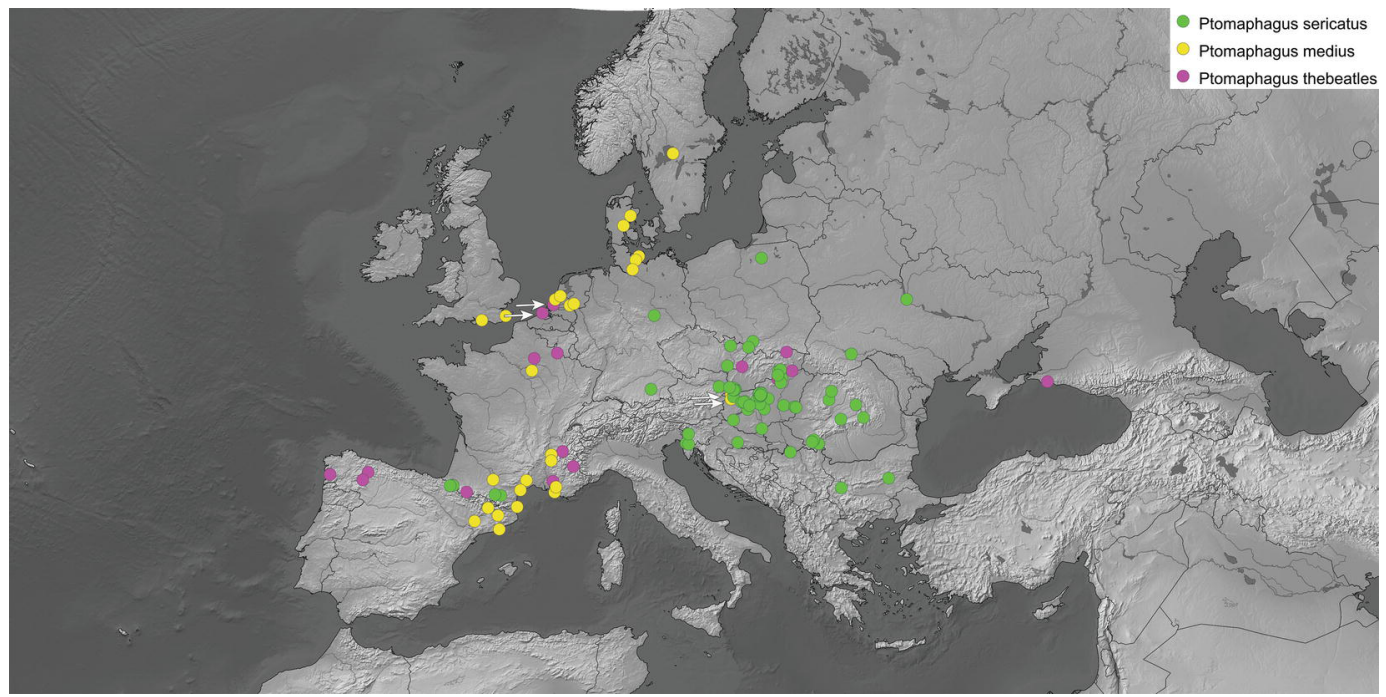

FIGURE 5 Distribution map of the specimens studied for this paper (the extralimital specimens of P. medius in Canada have not been included). The white arrows point at records that we interpret as recent range expansions.

\section{Distribution}

An east, central, and south-European species, reaching the Pyrenees in the west, northeastern Poland in the north, Bulgaria in the south, and central Ukraine in the east (fig. 5). Statements on its distribution in the older literature cannot be fully relied upon, since the species may have been confused with $P$. thebeatles and P. medius.

\section{Notes}

The type, from Kiev, is presumed lost. Chaudoir's collection is held in Paris, but Jeannel $(1934,1936)$ did not see the type, and subsequent authors (Sokolowksi, 1956; Perreau, 200o) have also been unable to locate it. Given that the identity of $P$. sericatus has been unclear, we therefore find it important to designate a neotype, from Kiev, the original type locality.

\section{DNA barcodes}

We have generated 11 DNA-barcodes for specimens from the south of France (LanguedocRousillon and Ariège; figs 6, 7). However, as these were generated with the internal 'Ron' and 'Nancy' primers (which avoid the amplification problems encountered with the 'Folmer' primers), they are less than 500 bp in length and therefore do not qualify for Barcode Identification Number (BIN). Genetic distance with $P$. thebeatles amounts to $c$. $3 \%$. Unfortunately, we were unable to obtain DNA barcodes for material from eastern and central Europe.

Ptomaphagus (Ptomaphagus) medius (Rey, 1889)

\section{Nomenclature}

Catops medius Rey, 1889 (Rey 1889: 5). Type series (from Lyon, Beaujolais, Collioure, and St. Raphael) in MC. Lectotype (here designated) in MC. Type locality: Pyrénées Orientales. Catops miser Rey, 1889 (Rey, 1889: 5); syn. n. 


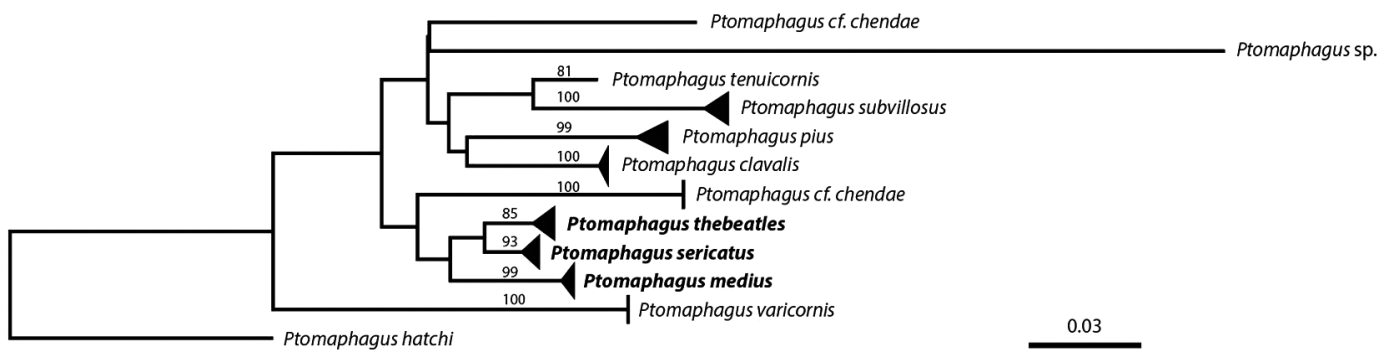

FIGURE 6 Maximum-likelihood phylogenetic reconstruction, based on COI sequences, of $P$. thebeatles, $P$. medius, $P$. sericatus, and other members of the subgenus Ptomaphagus s. str., rooted with $P$. (Adelops) hatchi. Multiple sequences per species have been collapsed. Support values are given only for branches with $>8 \circ \%$ bootstrap percentage.

Ptomaphagus sericatus septentrionalis Jeannel, 1934 (Jeannel, 1934: 169); syn. n.

Ptomaphagus sericatus medius (Rey, 1889) (Jeannel 1936: 87).

Ptomaphagus ruthenus auct. (Sokolowksi, 1956) (misidentification).

Ptomaphagusmedius (Rey, 1889) (Schilthuizen, 1989: 62-63).

Ptomaphagusmedius(Rey, 1889)(Schilthuizen, 2010: 2-3).

\section{Examined material}

\section{Type specimens}

Lectotype (here designated): [pale blue round label:] "Pyrénées Orientales / "[male symbol]" / [Red label:] "Catops medius / (Rey), male, LECTOTYPE / M. Schilthuizen design. 2016” 1 male in MC.

Lectotype of $P$. miser Rey (here designated): “C. miser”, no locality labels (therefore, probably from "région Lyonnais sensu lato" [Harold Labrique, pers. comm.]), [Red label:] "Catops miser (Rey), male, LECTOTYPE / M. Schilthuizen design. 2016”, 1 male in MC.

Syntype of P. miser Rey: "C. miser", leg. Rey, no locality labels (therefore, probably from "région Lyonnais sensu lato"; [Harold Labrique], pers. comm.), 1 male in MC.

Holotype of Ptomaphagus septentrionalis: "Schweden Alte Sammlung" / "TYPE” [red label] / "Ptomaphagus sericatus septentrionalis" 1 male in MNHN.

\section{Other examined specimens}

Denmark. East Sylland, Århus, Trondhjemsgade, compost with chicken leg, 7.v.1987, leg. Munk, 1 male in HNHM. Denmark, Veile, Bredballe, compost in garden, 7.viii.1994, leg. Munk, 1 male in HNHM. France. Crest, coll. A. Argod, 1 male in MNHN. St. Guilhem, Hérault, 1 male in MNHN. St. Remy la V., 5.iv.1913, leg. R. du Buysson, 1 male in MNHN. Toulouse, ix.19o4, leg. R. Jeannel, 1 male in MNHN. Marseille, coll. R. Jeannel, 1 male in MNHN. Pyrénées Orientales, Banyuls, iv.1905, coll. R. Jeannel, 1 male in MNHN. Aix-en-Provence, 1.ii.1922, coll. P. v.d. Wiel, 1 male in RMNH+ZMAN (ZMA.INS.1141394). France, iv.1899, coll. MacGillavry, 1 male in RMNH+ZMAN (RMNH.INS.631353). St. Guilhem, Hérault, leg. H. Lavagne, 1 male in $\mathrm{RMNH}+\mathrm{ZMAN}$ (ZMA.INS.1141348). m. Minsmer, 1899, coll. D. v.d. Hop, 1 male in RMNH+ZMAN (ZMA. INS.1141342). Provence, Vendres, leg. Normand, 1 male in RMNH+ZMAN (ZMA.INS.1141079). Aix-en-Provence, leg. Tisson, 1 male in HNHM. Germany. Holstein, Oldenburg, Putlos, in hollow willow, 22.iv.1933, leg. K. Sokolowksi, 1 male in HNHM. Holstein, Eutin, 11.x.1930, leg. Sick, 1 male in HNHM. Hamburg vicinity, Todendorf, 23.X.1938, leg. K. Sokolowski, 2 males in HNHM. Hungary. Györ-M.-S.m., 


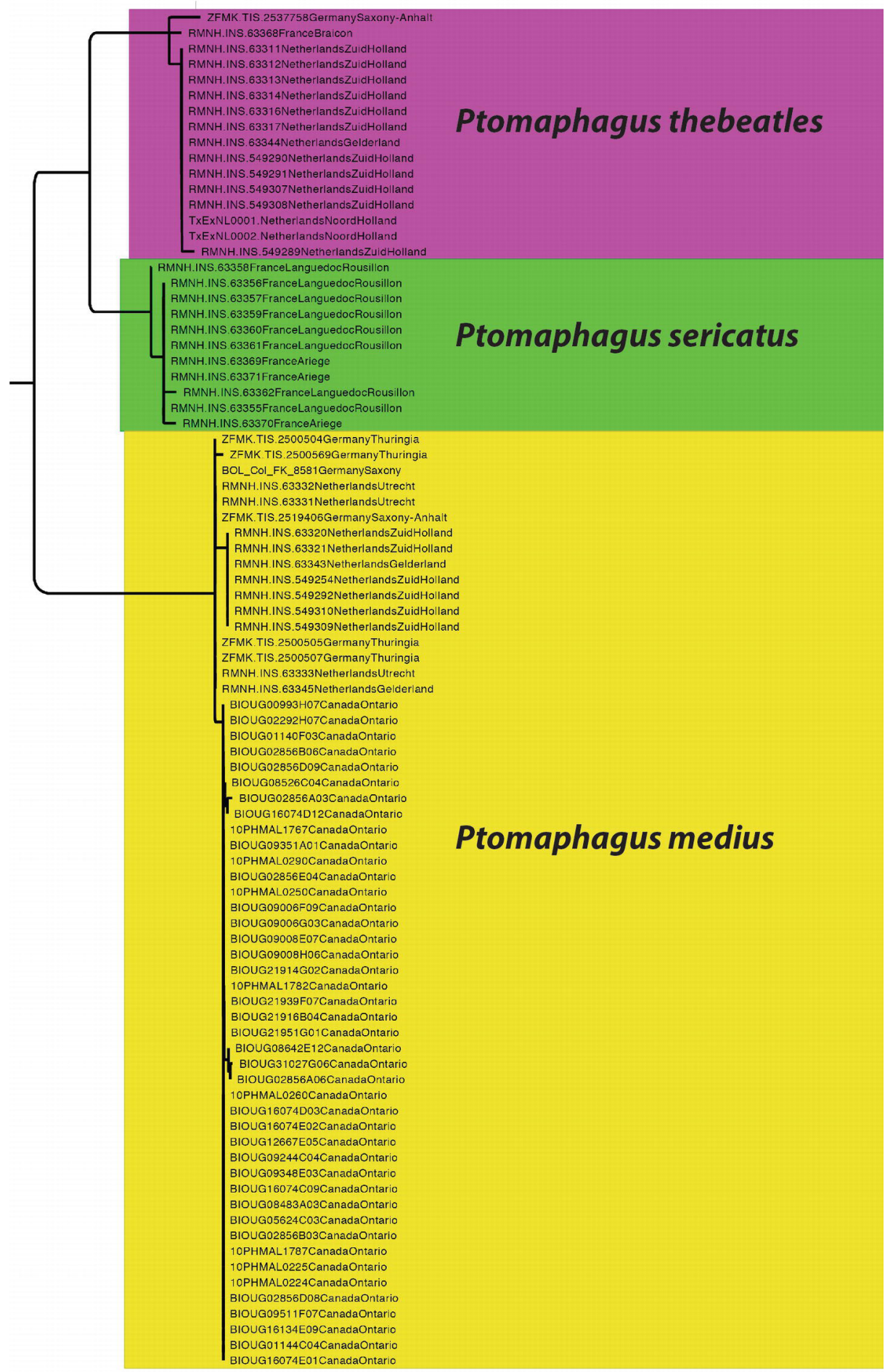

0.04

FIGURE 7 Enlarged section of the Maximum-likelihood phylogenetic reconstruction of fig. 6, with all COI sequences shown for the sericatus group, i.e., $P$. thebeatles, $P$. medius, and P. sericatus. Colours match those in fig. 5 . 
Osli, Tölösi-erdö, automobile-net, 18.30-19.oo h, 21.iv.20oo, leg. O. Merkl, 1 male in HNHM. GyörM.-S.m., Dénesfa, woody pasture, 29.iii.200o, leg. A. Podlussány, 1 male in HNHM. Spain. Barcelona, iii-iv.1927, 2 males in MNHN. Lérida, Cuevas clares de Gurp, xi.1920, leg. Zariquiey, 1 male in MNHN. Lérida, Noves de Segre, Forat de l'Infern, x.1929, leg. Dr. Zariquiey, 1 male in MNHN. The Netherlands. Oegstgeest, Leidse Hout, ii-iv.2011, leg. D. v.d. Horst, 8 males in $\mathrm{RMNH}+\mathrm{ZMAN}$ (RMNH.INS.63318-63321, RMNH.INS.549254, RMNH.INS.549292, RMNH. INS.549309-549310). De Blaauwe Kamer (nr. Wageningen), in flood debris, 28.xii.2012, leg. Dick Belgers, 3 males in RMNH+ZMAN (RMNH.INS.63331-63333).

Arnhem, Koningsheide, 26.vi-31.X.2013, leg. A. den Dees, 4 males in RMNH+ZMAN (RMNH.INS.6333163333, 63343). Amsterdam, Vondelpark, 6.iii7.v.2019, leg. Schilthuizen \& Van der Meer, 41 males in TXEX. United Kingdom. Chichester, E. Tottenham, coll. P. v.d. Wiel, 1 male in RMNH+ZMAN (ZMA.INS.1141143). UK, leg. Harwood, 1 male in MNHN. Kent, Wye, leg. B.S. Harwood, 1 male in MNHN.

Antennae (fig. 3c) more slender than in $P$. sericatus and $P$. thebeatles: $6^{\text {th }}$ antennomere c. 1.5 times as wide as long in the female, less than 1.5 times as wide as long in the male. Aedeagus (fig. 4a) in dorsal view gradually narrowed into a sharp point, in lateral view regularly bent ventrad. Apical orifice relatively far before the apex.

\section{Distribution}

The historical specimens suggest the species was, until recently, restricted to western and northern Europe (Sweden, Denmark, England, the Netherlands, northwestern Germany, France, northern Spain; fig. 5). However, the recent records from Canada (based on DNAbarcodes and imaged specimens in BOLD) and Hungary (among the large material of sericatus-group from Hungary in HNHM, the only true $P$. medius were of recent date) suggest that, like $P$. thebeatles, $P$. medius has recently undergone range expansions.

\section{Notes}

Jeannel (1934, 1936) described P. sericatus subsp. septentrionalis as a Scandinavian taxon, differing from medius by the more slender antennae and aedeagus. There is some variation in these traits within medius, but we failed to find consistent differences that would justify the recognition of a separate taxon. Although since Jeannel, most authors have ignored septentrionalis, we here for the first time formally synonymise it with $P$. medius.

\section{DNA barcodes}

All confirmed $P$. medius DNA-barcodes from Europe fall within the BIN AAU6931 of BOLD. The same BIN also contains a large number of BOLD-records collected in a 400-km wide strip north of Lake Ontario, Canada. Genetic distances with $P$. sericatus and $P$. thebeatles are c. $5 \%$ (fig. 7 ).

\section{Ptomaphagus (Ptomaphagus) thebeatles} Schilthuizen, Latella \& Njunjić, 2020, sp.n. Nomenclature

Ptomaphagus sericatus (Chaudoir, 1845) (Schilthuizen 1989: 61)

Ptomaphagus sericatus (Chaudoir, 1845) (Schilthuizen 2010: 2-3)

\section{Examined material}

\section{Type specimens}

Holotype: "The Netherlands: prov. NoordHolland, Amsterdam, Vondelpark, Koeienweide, $52.355^{\circ} \mathrm{N} 4.8585^{\circ} \mathrm{E}, 25$. .iii.2O19, 
leg. Taxon Expeditions participants" / "Ptomaphagus thebeatles Schilthuizen et al., HOLOTYPE" (red label) / RMNH.INS.63376", deposited in RMNH. Body size of the holotype is $2.7 \mathrm{~mm}$. Type locality is Amsterdam.

\section{Other examined specimens}

France. Grenoble, leg. D. Guedel, 1 male in MNHN. Soissons, leg. De Buffévent, 1 male in MNHN. Monts Luberon, 2o.x.1904, leg. Ch. Fagniez, 1 male in MNHN. Sedan, xi.1883, leg. Des Gozis, 1 male in RMNH+ZMAN (ZMA. INS.1140958). Hautes-Pyrénées, Cauterets, coll. E. Everts, 1 male in RMNH+ZMAN (ZMA.INS.1141363). Braicon near Embrun, $44.521800^{\circ} \mathrm{N} 6.474050^{\circ} \mathrm{E}$, 1.ix.2013, leg. W. v. Oostenbrugge \& $\mathrm{S}$. Visser, 1 male, 1 female in RMNH+ZMAN (RMNH.INS.63367-63368). Hungary. Bükki National Park, Szilvásvárad, Tar-kö, 950 m, talajcsapda, 24.viii.1981, leg. Ádám, 1 male in HNHM. Hungary, leg. E. Frivaldszky, 1 male in HNHM. Pálháza Com., Zemplen, Istvánkút 6-11.vii.1955, leg. Kaszab \& Szekessy, 1 male in HNHM. Romania. Herkulesfürdó, 1879, leg. Pável, 2 males in HNHM. Russia. Novorossiysk, 25.iii.1874, coll. E. Reitter, 2 males in HNHM. Slovakia. Szelecz, Kocsi, 1 male in HNHM. Bártfa, leg. Mihalovics, 1 male in HNHM. Spain. Caril, leg. Paganetti, 1 male in RMNH+ZMAN (ZMA.INS.1141332). Barcelona, 3.iv.1927, 1 male in MNHN. Caboalles, leg. G. Paganetti, 1 male in RMNH+ZMAN (ZMA.INS. 1140941). Ponferrada, leg. Paganetti, 1 male in HNHM, 2 males in RMNH+ZMAN (ZMA. INS.1141356-1141357). The Netherlands. Leiden, ii-iv.2011, leg. D. van der Horst, 5 males in RMNH+ZMAN (RMNH.INS.63311, RMNH.INS.63313, RMNH.INS.63314, RMNH. INS.63316, RMNH.INS.63317). Arnhem, Koningsheide, 26.vi.-31.x.2013, leg. A. den Dees, 1 male in RMNH+ZMAN (RMNH. INS.63344). Oegstgeest, Leidse Hout, 1.iii.2o.iv.2011, leg. D. van der Horst, 5 males in RMNH+ZMAN (RMNH.INS.549289-549291,
549307-549308). Schiedam, Beatrixpark, pitfall with cheese, 19.vii.1987, leg. M. Schilthuizen, 1 male in $\mathrm{RMNH}+\mathrm{ZMAN}$ (RMNH.INS.634264). Schiedam, pitfall with carrion, 19.iv.1983, leg. M. Schilthuizen, 1 male in RMNH+ZMAN (RMNH. INS.634239). Middelburg, pitfall with cheese, 29.vii.1987, leg. M. Schilthuizen, 1 male in RMNH+ZMAN (RMNH.INS.634265). Amsterdam, Vondelpark, 25.iii-9.viii.2019, leg. Taxon Expeditions participants, 6 males in TXEX.

Antennae (fig. 3b) more robust than in $P$. sericatus and P. medius: $6^{\text {th }}$ antennomere 2 times as wide as long in the male, 2.5 times as wide as long in the female. Aedeagus (fig. 4c) apex in dorsal view similar to $P$. sericatus, but more narrowed and with an even blunter apical angle; in lateral view clearly sinuous (sunken near the orifice); apical orifice very close to the tip, basal edge \pm in line with the end of the parameres.

\section{Etymology}

Named for the band The Beatles, which no beetle has yet been named after. The name also commemorates the 'Bed In for Peace' by John Lennon and Yoko Ono in the nearby Hilton Hotel, exactly 50 years (to the day) prior to the collection date of the holotype.

\section{Distribution}

This species has a wide distribution across southern and western Europe (fig. 5). It reaches southern Russia in the east and Spain in the west. In recent decades, it appears to have shifted or extended its distribution northward: whereas specimens from northern France date back to the late 19th century, all material from The Netherlands dates only from the past 35 years. 


\section{Notes}

The existence of this previously unrecognized species is probably one of the causes for much of the confusion regarding the sericatus-complex over the past century. The shape of the aedeagus of $P$. medius is strikingly different from that of $P$. thebeatles, and workers who had access to many $P$. thebeatles specimens would have considered these as $P$. sericatus and as different from $P$. medius at the species level. On the other hand, researchers whose image of $P$. sericatus was formed mostly by specimens of the true $P$. sericatus, of which the aedeagus shape is somewhat intermediate between $P$. thebeatles and $P$. medius, may have been more dubious about its specific status.

\section{DNA barcodes}

We have obtained 16 closely-related DNAbarcodes for specimens from France, the Netherlands, and Germany (fig. 7), most of which were confirmed with genital dissection. These sequences were either obtained from GenBank or generated with the internal 'Ron' and 'Nancy' primers (which avoid the amplification problems encountered with the 'Folmer' primers), and less than 500 bp in length. In both situations, they do not qualify for a Barcode Identification Number (BIN) to be determined. Genetic distance with $P$. sericatus amounts to c. $3 \%$.

\section{Discussion}

Our study, which was partly conducted by citizen scientists in an urban park in Amsterdam, shows that there is scope for urban taxonomy: primary taxonomic studies carried out in urbanised areas by their inhabitants. In fact, during the same field trip that yielded $P$. thebeatles, we also discovered and described a new species of braconid wasp (Van Achterberg et al., 2020a). Many invertebrate taxa are so poorly studied, even in densely populated areas and even in well-studied countries like the Netherlands, that new species remain to be discovered in streets, backyards, and city parks. Moreover, recent shifts in distribution, caused directly or indirectly by human action, will lead to urban taxa that may be new arrivals in the country in question (Van Achterberg et al., 2O2Ob). Indeed, the transatlantic expansion of $P$. medius was first detected in a private garden in Canada (S.B. Peck, pers. comm.). And, based on the distribution localities and dates, it seems likely that the new $P$. thebeatles has only arrived in the Netherlands in the past few decades, possibly as a result of climate change, without which it may have taken longer to have been noticed. Involving city inhabitants in these studies and highlighting them to the local authorities may serve several benefits (Schilthuizen et al., 2017). First, it may raise the conservation value of the urban greenspace where the new species is discovered. Second, it makes urbanites aware of the undiscovered biological richness of their immediate surroundings. Finally, it increases awareness about the field of taxonomy and the gaps in our knowledge for large parts of our local biodiversity.

\section{Acknowledgements}

Dr. Ottó Merkl and his staff were extremely hospitable and helpful during a SYNTHESYS visit of the first author to the Hungarian Museum of Natural History in Budapest, 2015. Mme. Azadeh Taghavian supported the author during a visit to the Muséum National d'Histoire Naturelle, Paris. Mr. Harold Labrique kindly arranged for the loan of specimens from the Claudius Rey collection in the Musée des Confluences, Lyon, France. Dr. Jiří Hájek allowed us to study some specimens in the collection of Natural History Museum, Prague. Mr. Hans Huijbregts helped 
with organising material from Naturalis. Dr. Jan van Tol advised on matters of typification. Some of the DNA sequences were generated by Roland Butôt, Jessy Dommershuijzen, Cindy Scholte, Iris Sipman, Devi van der Horst, and Renske van Wijk. Erik-Jan Bosch is kindly acknowledged for his beautiful drawing for Fig. 1. Remco Daalder, and other urban ecologists of the municipality of Amsterdam were helpful in assisting with the organisation of the Vondelpark expedition by Taxon Expeditions, which allowed the collecting of the holotype and the description of $P$. thebeatles $\mathrm{n}$. sp. SEM-photos were prepared with the help of Roel van Elsas, Vrije Universiteit, Amsterdam. This research received support from the SYNTHESYS Project http://www.synthesys.info/ which is financed by European Community Research Infrastructure Action under the $\mathrm{FP}_{7}$ "Capacities" Program, and from the Uyttenboogaart-Eliasen Foundation. An earlier version of this paper was improved by comments from Jan Ružička and Javier Fresneda. We acknowledge two anonymous reviewers, whose comments helped improve the paper.

\section{Supplementary material}

Supplementary material is available online at: https://doi.org/10.6o84/mg.figshare.12249788

\section{References}

Achterberg, C. van, Schilthuizen, M., Van der M eer, M., Delval, R., Dias, C., Hoynck, M., Köster, H., Maarschall, R., Peeters, N., Venema, P., Zaremba, R., Beltrami, C., Nieuwenhuis, F., De Rop, N., Njunjić, I. \& Koene, J. (2020a) A new parasitoid wasp, Aphaereta vondelparkensis sp. n. (Braconidae, Alysiinae), from a city park in the centre of Amsterdam. Biodivers. Data J., 8, e49017.
Achterberg, C. van, Chen, X.X. \& Schilthuizen, M. (2020b) Exotic Chinese wasp, Perilitus erratus Chen \& van Achterberg (Hymenoptera: Braconidae: Euphorinae) in the centre of Amsterdam. Entomolog. Ber., (in press).

Brancsik, K. (1907) Adalek Trencsénvármegye Coleoptera-faunájához. Rovartani Lapok, 14, 58-65.

Chaudoir, M. (1845) Notices entomologiques sur le gouvernement et la ville de Kiew. Bulletin de la Société Impériale des Naturalistes de Moscou, 18, 158-213.

Guindon, S., Dufayard, J., Lefort, V., Anisimova, M., Hordijk, W. \& Gascuel, O. (2010) New algorithms and methods to estimate maximum-likelihood phylogenies: Assessing the performance of PhyML 3.o. Syst. Biol., 59, 307-321.

Hatch, M. (1928) Coleopterum Catalogus, Pars 95: Silphidae II. W. Junk, Berlin.

ICZN (1999) International Code of Zoological Nomenclature. ICZN, London.

Jeannel, R. (1934) Les Ptomaphagus paléarctiques. Revue Française d'Entomologie, 1, 161-170.

Jeannel, R. (1936) Monographie des Catopidae. Mémoires du Muséum National d'Histoire Naturelle (Nouvelle Série), 1, 1-433.

Maestri, S., Cosentino, E., Paterno, M., Freitag, H., Garces, J., Marcolungo, L., Alfano, M., Njunjić, I., Schilthuizen, M., Slik, F., Menegon, M., Rossato, M. \& Delledonne, M. (2019) A rapid and accurate MinION-based workflow for tracking species biodiversity in the field. Genes, 10, 468.

Perreau, M. (2000) Catalogue des Coléoptères Leiodidae Cholevinae et Platypsyllinae. Mémoires de la Société Entomologique de France, 4, 1-46o.

Rey, C. (1889) Remarques en passant: famille des Catopidés. L'Echange, 5, 4-5.

Schilthuizen, M. (1989) Nieuwe gegevens over de Nederlandse choleviden-fauna (Coleoptera: Cholevidae). Entomolog. Ber., 49, 61-64.

Schilthuizen, M. (2010) Catops borealis Krogerus, 1931, new to the British fauna, and some notes on other British Cholevinae (Leiodidae). The 
Schilthuizen, M., Seip, L., Otani, S., Suhaimi, J. \& Njunjić, I. (2017) Three new minute leaf litter beetles discovered by citizen scientists in Maliau Basin, Malaysian Borneo (Coleoptera: Leiodidae, Chrysomelidae). Biodivers. Data J. 5 , e21947.

Seidlitz, G. (1887) Zur genaueren Kenntniss einiger Catops-Arten Europas. Deutsche Entomologische Zeitschrift 1887 (1), 81-94.

Shorthouse, D.P. (2010) SimpleMappr, an online tool to produce publication-quality point maps. Available from http://www.simplemappr.net

Simon, C., Frati, F., Beckenbach, A., Crespi, B., Liu, H. \& Flook, P. (1994) Evolution, weighting, and phylogenetic utility of mitochondrial gene sequences and a compilation of conserved polymerase chain reaction primers. Ann. Entomol. Soc. Am., 87, 651-701.

Sokolowski, K. (1949) Bestimmungstabelle der mitteleuropäischen Arten der Gattung Ptomaphagus Illiger. Koleopterologische Zeitschrift, 1, 13-14.
Sokolowski, K. (1956) Die mitteleuropäischen Ptomaphagus Arten (Col.) (Catopidenstudien V). Entomologische Blätter für Biologie und Systematik der Käfer, 52, 176-181.

Szymczakowski, W. (1971) Fam. Catopidae. In: Freude, H., Harde, K.W. \& Lohse, G.A. (Eds) Die Kafer Mitteleuropas 3, pp. 204-236. Goecke \& Evers, Krefeld.

Zwick, P.(1983) Faunistik der Hessischen Koleopteren: Familie Cholevidae (= Catopidae). Mitteilungen des Internationalen Entomologischen Vereins, Frankfurt/M, 8, 61-94.

RECEIVED: 13 APRIL 2020 | REVISED AND

ACCE PTED: 5 MAY 2020

EDITOR: R. VONK 